\title{
Annual Bioenergy Crops for Biofuels Production: Farmers' Contractual Preferences for Producing Sweet Sorghum
}

\section{Jason S. Bergtold ${ }^{\mathrm{a}}$, Aleksan Shanoyan ${ }^{\mathrm{b}}$, Jason E. Fewell ${ }^{\mathrm{c}}$ and Jeffery R. Williams ${ }^{\mathrm{d}}$}

${ }^{a}$ Associate Professor, 342 Waters Hall, Department of Agricultural Economics, Kansas State University, Manhattan KS, USA, 66506-4011; email: bergtold@ksu.edu; phone: (785) 5320984; fax: (785) 532-6925 (Corresponding author)

${ }^{\mathrm{b}}$ Assistant Professor, 342 Waters Hall, Department of Agricultural Economics, Kansas State University, Manhattan KS, USA, 66506-4011; email: $\underline{\text { shanoyan@ksu.edu }}$

${ }^{\mathrm{c}}$ Farm Business Management Director, 1801 College Drive N., Lake Region State College,

Devils Lake, ND, USA, 58301; email: jason.fewell@1rsc.edu

${ }^{\mathrm{d}}$ Professor, 342 Waters Hall, Department of Agricultural Economics, Kansas State

University, Manhattan, KS, USA, 66506-4011; email: jwilliam@ksu.edu 


\title{
Annual Bioenergy Crops for Biofuels Production: Farmers' Contractual Preferences \\ for Producing Sweet Sorghum
}

\begin{abstract}
Dedicated annual sorghum crops, such as sweet sorghum or energy sorghum, may provide an option for farmers to supply cellulosic feedstocks for biofuel production and help the industry meet government mandates. Kansas farmers are poised to be major producers of sweet sorghum for biofuels due to favorable agro-ecological conditions. The purpose of this paper is to assess Kansas farmers' willingness to grow sweet sorghum under contract as a feedstock for biofuel production. The paper examines farmers' willingness-to-pay for contract attributes and the impact of socio-economic factors on their willingness-to-pay for these attributes. A stated choice survey was administered to Kansas farmers to assess their willingness to grow sweet sorghum for biofuels under various contracting scenarios. Results show that farmers may be willing to grow biomass for bioenergy under contract, but may have varying preferences for the importance of contract attributes such as net returns, contract length, insurance availability, government incentives, and potential for biorefinery harvest options based on socio-economic characteristics of growers.
\end{abstract}

Keywords: Biofuels, Contract, Mixed Logit, Sorghum, Willingness-to-Pay 


\section{Annual Bioenergy Crops for Biofuels Production: Farmers' Contractual Preferences for Producing Sweet Sorghum}

\section{Introduction}

The Energy Independence and Security Act of 2007 states, in part, that biofuel production must increase to 36 billion gallons by the year 2022, of which 21 billion gallons must come from "advanced" or second-generation biofuel feedstocks, which includes dedicated annual bioenergy crops [1]. To date, cellulosic biofuel production has significantly fallen short of set goals and mandates due to economic feasibility concerns, market development issues, and uncertainties about government policy [2-4]. Among important preconditions for meeting set goals is the agricultural producers' willingness to grow biomass crops. While the literature in this area has grown over the last decade, many important questions still remain about appropriate incentive mechanisms and viability of alternative bioenergy crop varieties [5].

Dedicated annual bioenergy crops provide a potentially viable biofuel feedstock enterprise option for farmers. They can serve as a flexible alternative cash crop for farmers that can be grown in traditional crop rotations. For example, sweet, energy or forage sorghum varieties may serve as annual bioenergy crops. There are several advantages to these types of sorghum crops, including production of high amounts of biomass, drought tolerance and the ability to incorporate them into existing crop rotations [6]. This study focuses on the use of sweet sorghum specifically, though forage and energy varieties of sorghum would be viable substitutes. Management of sweet sorghum is similar to grain and forage sorghum under dryland conditions. Propheter, et al. [7] found favorable yields for different sorghum varieties in the less than ideal growing conditions in Kansas. They also found that these annual crops produced more usable biomass than perennial options during the study period, which 
increases appeal of crops such as sweet sorghum for biofuels in the Great Plains of the United States.

To ensure the viability of biofuel production from cellulosic feedstocks, it is important to know under which conditions farm managers will be willing to produce cellulosic biofuel feedstocks. Farmers are more likely to supply cellulosic biofuel feedstocks if the expected payoff from the enterprise is greater than any other possible land use [8]. However, Rajagopal and Zilberman [5] indicate that the factors that lead to farmers' adoption of biofuel technologies are still not well understood. Among such factors is the coordination of transactions at the producer-processor interface of the cellulosic biofuel supply chain, specifically the nature of contractual arrangements.

Contract theory and transaction cost literature delineates various strategies for coordinating transactions along the supply chain. These strategies form a vertical coordination continuum ranging from simple spot market transactions to complete vertical integration [9]. Empirical studies have identified a variety of coordination strategies including contracts and equity arrangements and have shown that when transactions involve high levels of risk and uncertainty, strategies with higher levels of vertical integration are preferred [10-12]. Specification contracting is one such strategy that involves establishment of legally enforceable conditions of exchange. With appropriate specifications, contractual arrangements can reduce the uncertainty associated with price and revenue for producers, while allowing processors to gain more influence over coordination without all the risk and rigidity associated with equity-based arrangements.

The fact that the markets for cellulosic biofuel feedstock are still underdeveloped or nonexistent creates an extra level of risk and uncertainty for farmers in addition to traditional weather and price uncertainty. Under these conditions, vertical coordination through specification contracts between growers of cellulosic biofuel crops (e.g. sweet sorghum) and 
ethanol producers can represent a potential solution. The question then becomes, what transaction attributes should be specified in such contracts. Based on contract literature and empirical studies of various agricultural commodity markets, contractual arrangements between growers and processors are likely to be affected by multitude of factors, including contract pricing, timeframe, acreage commitments, risk, timing of harvest, yield variability, feedstock quality, harvest responsibilities (e.g. custom harvesting), nutrient replacement, location of biorefineries, available cropping choices, technology, and conservation considerations [13-18].

The purpose of this study is to examine farmers' willingness to produce sweet sorghum under alternative contractual, pricing, and harvesting arrangements in Kansas. Assessment of farmers' willingness to adopt a sweet sorghum enterprise under different contractual arrangements is implemented using an enumerated field survey with stated choice techniques. The survey examines farmers' willingness-to-pay for different contract attributes and how alternative socio-economic and farm factors may impact their contractual preferences. A stated choice approach following Louviere et al. [19] is used to assess farmers' willingness to adopt. Survey results are analyzed using a random parameters conditional logistic regression model [20-21]. A unique contribution of this paper is the estimation of marginal effects of socio-economic and farm characteristics on the willingnessto-pay for specific contract attributes. The paper extends the literature on biomass contracting by providing empirical insights into the importance of key contract attributes for supplying dedicated annual bioenergy crops given the specific socio-economic characteristics of growers.

The rest of the paper is organized as follows, section two provides some needed background on prior literature. Section three presents the description of survey method and data, as well as the details of the stated choice experiment. The empirical model and the 
estimation methods are presented in section four, followed by the results and concluding remarks in sections five and six.

\section{Biofuel Feedstock Contracting and Adoption}

A large amount of research exists on the technical feasibility of growing cellulosic biofuels (including biomass yield and production potential), as well as farmgate and breakeven pricing (e.g. [22 - 33]). However, these studies do not evaluate farmer' willingness to grow a dedicated bioenergy feedstock. In addition, this research does not identify the characteristics of farmers that would provide that feedstock. While these studies provide a large amount of useful information and insight, they may be of little relevance if farmers are not willing to grow bioenergy crops for biofuel production.

A small number of studies has examined farmers' willingness to grow bioenergy crops, especially under contract. Hipple and Duffy [34] used personal interviews to examine farmers' willingness to grow switchgrass in Iowa. Factors impacting willingness to grow included profitability, return on investment, complexity, and economic sustainability. Quality of life issues were also considered important, including compatibility with personal and family values and beliefs, health and safety, environmental, and aesthetic issues.

Jensen et al. [35] assessed Tennessee farmers' willingness to grow switchgrass on their land. They found that average higher net farm income per acre decreased the likelihood of growing switchgrass, as the opportunity cost of converting land may be too high. In addition, they found that the requirement of signing a long-term contract would likely decrease the likelihood of planting switchgrass.

Sherrington et al. [36] examined farmers' willingness to grow dedicated perennial bioenergy crops in the United Kingdom. They found that factors impacting farmers' willingness to grow using focus groups included: potential financial returns and competition 
with other potential land uses; uncertainty about the financial viability of growing bioenergy crops and markets; the requirement for financial incentives to grow dedicated bioenergy crops due to high establishment costs; need for contracts due to limited markets; and environmental impacts.

Paulrud and Laitila [37] examined farmers' willingness to grow dedicated perennial bioenergy crops (e.g. willow and canary grass) in Sweden. They utilized a stated choice experiment for a generic dedicated perennial bioenergy crop. The authors find that farmers are willing to accept less net returns if the crop can be grown under contract; a farmer would require higher returns from the crop the longer the rotational period; government subsidies for growing a dedicated perennial bioenergy crop have no direct impact on farmer's willingness to grow the crop; and net income from crop production increased the likelihood of planting a dedicated perennial bioenergy crop.

Qualls et al. [38] examined farmers' willingness to grow switchgrass in 12 southeastern U.S. states. Of interest, was the result that as the price per unit of switchgrass increased, the amount of land a farmer was willing to plant to switchgrass increased. In addition, they found that prior experience with producing a commodity under contract reduced farmers' interests if they were willing to covert land to switchgrass production.

Altman et al. [39] examine farmers' willingness to harvest alternative sources of crop residues (e.g. corn stover and wheat straw) and hay in Illinois and Missouri. They find that supply for all the feedstocks is highly elastic (ranging from 2 to 10, depending on the feedstock and location). That is, as the price of a feedstock increases, farmers' willingness to supply that feedstock increases greater than the percentage increase in price. Thus, price plays a significant factor in farmers' willingness to harvest crop residues and hay as a bioenergy feedstock. 
Alexander et al. [40] indicate that contract length will be particularly important for contracts for growing dedicated annual bioenergy crops. These crops do not have a long establishment period like dedicated perennial bioenergy crops and they can fit into traditional cropping systems, only requiring a short-term commitment by the farmer. Longer term contracts for these types of crops may reduce the flexibility that dedicated annual bioenergy crops can provide. In addition, refineries will have to still take storage and transportation issues into consideration when contracting directly with farmers. Golecha and Gan [41] show that price incentives for biomass suppliers (e.g. farmers) will be an important part of any contracting strategy by a biorefinery and such strategies may be useful in reducing biomass supply volatility.

The manuscript provides a novel contribution to the literature by focusing on farmers' willingness to grow dedicated annual bioenergy crops under contract, whereas most of the prior literature has predominately focused on crop residues and dedicated perennial bioenergy crops. In addition, the manuscript provides a unique perspective on the conditions under which farmers' would contract to grow a dedicated annual bioenergy crop and the socioeconomic factors that may impact their contract preferences.

\section{Survey Methods and Data}

A stated choice survey was administered from November 2010 to February 2011 in northeastern, south central, and western Kansas by Kansas State University and the USDA, National Agricultural Statistics Service (NASS). The purpose of the survey was to assess farmers' willingness to produce cellulosic biomass in the form of corn stover, sweet sorghum, and switchgrass for bioenergy production under different contractual arrangements. A total of 485 farmers were contacted to participate in the survey. The areas of Kansas were selected 
based on the number of farms growing corn and/or sorghum; the mix of irrigated and dryland production; and mix of crops and farming practices adopted.

For each area of the state examined, the sample of farms was randomly drawn from the population of farms over 260 acres in size and $\$ 50,000$ in gross farm sales from the USDA-NASS farmer list. Farmers already participating in other USDA-NASS enumerated surveys (e.g., ARMS) were removed from the sample and replaced with another randomly drawn name. Prior to the survey entering the field, the stated choice component was field tested with two focus groups at an annual extension conference hosted by the Department of Agricultural Economics at Kansas State University in the summer of 2010. Participants who were identified as farmers were invited to attend the focus group, of which 12 participated. In addition, the entire survey was tested using face-to-face interviews with farmers in the targeted study areas.

Potential participants received a four-page flier via mail asking for their participation in the survey and providing information about cellulosic biofuel feedstock production onfarm one week prior to being contacted by USDA-NASS enumerators. Enumerators then scheduled one-hour interviews with the farmers to complete the survey and stated choice experiments. Interviews, on average, took 57 minutes to complete. Upon completion of the survey and receipt at the USDA-NASS office, farmers were compensated for their time with a $\$ 15$ gift card. Of the 485 farmers contacted, 290 completed the survey and 38 were out-ofbusiness, did not farm, or could not be located. Thus, the survey response rate was (290/(485$38))=0.65$ or 65 percent. Of the 290 respondents who completed the stated choice experiment for sweet sorghum, 13 surveys were incomplete due to lack of responses on the experiment or refusal to answer demographic questions, leaving 277 usable surveys for this study. 
After answering a number of questions about their farming operation, respondents were asked about their willingness to produce cellulosic biofuel feedstocks under contract. Respondents were given three separate stated choice experiments examining their willingness to contract to produce or harvest corn residue, sweet sorghum and switchgrass. The survey was designed so that the responses from each stated choice experiment were independent of the others. Survey respondents were asked to consider each experiment individually and assume they were independent (e.g. not grown together) of the other experiments by the survey enumerator. In addition, the order of the experiments was randomized across different survey versions to avoid potential bias from the ordering of the stated choice experiments. This paper focuses on the stated choice experiment for sweet sorghum. Respondents were then asked about biofuel feedstock production preferences and perceptions; conservation onfarm and perceptions; risk management practices and perceptions; crop marketing practices; and demographics. A set of descriptive statistics for a select number of socio-economic and farmer demographic variables used in the study are provided in Table 1.

Farmer demographics taken from the 2012 U.S. Census of Agriculture [42] were used to assess the generalizability of the survey sample to the general farmer population with farms above 260 acres in size and $\$ 50,000$ in gross farm sales. The average age of surveyed farmers was 55.1 years, which was slightly lower than the Census average of 58.6 years. Average farm size and the amount of land rented from the survey sample (2172 acres and 1271 acres, respectively) were larger than the Census averages for Kansas (1553 acres and 1017 acres respectively). While these averages may not be significantly different, the differences may be due to the targeted areas for the survey within the state. The survey asked respondents to choose a category in which their value of agricultural product sales occurred, the Census of Agriculture amount of $\$ 448,317$ was slightly larger than the most often selected category of $\$ 200,000$ to $\$ 399,999$ by respondents on the survey. Farms with the 
resources and flexibility to produce these types of crops were desired for the survey sample. Larger farms produce most of the crop output in Kansas.

\subsection{Stated Choice Experiment}

A stated choice experiment was designed to assess farmers' willingness to enter into a contract with a bio-refinery or other biomass processor for producing sweet sorghum following Louviere et al. [19] and Roe et al. [43]. Farmers where presented with information about sweet sorghum production and contract attributes before answering a set of stated choice questions. Survey participants where then asked to consider 5 independent choice scenarios, where they were asked to select between two biomass contracts or an "opt out" option (Figure 1). Each contract option was unlabeled and had five attributes: (1) net returns above corn/sorghum production; (2) contract length; (3) biorefinery harvest; (4) insurance availability; and (5)

government incentive payments. Descriptions and levels for each contract attribute are provided in Table 2.

The net returns attribute captures both expected net returns and the opportunity cost of not planting another cash crop. Farmers were asked to assume a base value of $\$ 50$ for net returns from dryland corn/sorghum production for all scenarios presented. This base level represents the average net returns from Kansas Farm Management Association Farms (KFMA) [44] in the study region(s) for 2008/9. Thus, net returns are not fixed to a specific dollar amount, but can be compared relative to other crops using the attribute level for net returns above expected corn/sorghum production. For the purpose of data analysis, this 
attribute was recoded into a dollar amount by multiplying the percentage increase by the $\$ 50$ base. The net returns attribute provides flexibility in allowing the capture of reservation prices and potential opportunity costs, allowing prices to "float" to levels that will entice farmers to adopt this enterprise.

The second attribute was contract length. The increasing length of the contract represents the need of the refinery or biomass processor to mitigate risk by ensuring a longterm supply of biomass. The third attribute was a binary attribute for biorefinery harvest. This attribute provided the option to the farmer of having the biorefinery or intermediate processor harvest the biomass from the field and transport it to the refinery/processor. It was assumed that the cost of this practice was included in net returns. The fourth attribute was insurance availability, a binary attribute indicating if crop insurance was available to purchase under the contract. The availability of crop insurance can significantly effect the choice to plant a crop [45]. All binary attributes were effects coded.

The final attribute was a government incentive payment that is similar to that provided under the Biomass Crop Assistance Program (BCAP) [46]. The attribute had two levels, which were set to represent the match the government pays as a percentage of the price paid by the refinery for every ton of biomass produced and delivered. Furthermore, the incentive was not included in the net returns attribute described above. It was decided to not include this as part of the net returns, so that the direct impact of this type of incentive on farmers' willingness to grow sweet sorghum under contract could be assessed. In addition, the attribute directly impacts the price received for the feedstock by the farmer, which may be hard to disentangle with returns within a stated choice context. Given the use of substantial subsidies to promote cellulosic biofuel production, this attribute plays an important role for policy analysis. 
Following Louviere et al. [19], a $\left(2^{4} \times 3 \times 4\right)^{2}$ fractional factorial experimental design was used to design the choice sets for the sweet sorghum experiment. PROC OPTEX in SAS [47] was used to develop the fractional factorial design from the complete factorial to obtain 90 random choice scenarios, which were then blocked into 18 choice sets of 5 choice scenarios each. The $D$-optimality criterion was used to obtain an optimal design using a modified Federov search algorithm (see [48]). Optimal blocking was determined following the method outlined in Cook and Nachtsheim [49]. An optimal (treatment) D-Efficiency of $87.1 \%$ was obtained. The number of choice sets was selected in order to identify all main effects and potential interaction effects between contract attributes and levels. Each respondent was faced with 5 choice scenarios for each feedstock alternative, with 18 versions of the survey. Of the 290 surveys completed, 12 to 20 of each version were completed by farm managers.

\section{Model}

Following Roe et al. [43], we assume that producers want to maximize expected discounted utility when choosing to enter into a contract to produce sweet sorghum versus producing corn or grain sorghum over time. Let producer's $j$ 's expected discounted utility for contract option $i$ be given by:

$V_{j, i}=V\left(\Delta R_{i}\left(B_{i}, S_{i}\right), C_{i}, G_{i}\right)+\varepsilon_{j, i}$,

where is $\Delta R_{i}$ is the net returns above dryland corn/grain sorghum production over time, which includes the costs associated with $B_{i}$, indicating if a biomass harvest option is part of contract $i$, and $S_{i}$, indicating if crop insurance is available. In addition, expected discounted utility is a function of $C_{i}$, or the length of the contract in years; and $G_{i}$, or the level of government incentive payment. The error term, $\varepsilon_{j, i}$ represents the nonsystematic part of expected utility that goes unobserved by the modeler and is distributed type I extreme value 
[19]. It should be emphasized, that the inclusion of $\Delta R_{i}$ captures the return above the next best alternative for sweet sorghum. This is unique to this experimental set-up and important in that there will be competing uses for the land. Thus, the experimental set-up takes into account the potential next best alternatives for the land.

For the purposes of this study we are primarily interested in examining the direct impact of the contract attributes on producers' willingness to adopt or enter into a contract. Following Roe et al [43], we focus on the reduced-form representation of expected utility. The econometric model is based upon a conditional logistic regression model [20]. That is, for producer $j$ and contract $i$ :

$V_{j, i}=\beta_{0}+\beta_{1} \Delta R_{i}+\beta_{2} C_{i}+\beta_{3} B_{i}+\beta_{4} S_{i}+\beta_{5} G_{i}+\varepsilon_{j, i}$, for $j=A, B$ or $C$.

Contract choices $A$ and $B$ represent the randomly assigned unlabeled contract choices presented in each choice scenario, while option $C$ is the "opt out" or "do not adopt" option. Given option $C$ has no attribute levels $\beta_{k}=0$ for $k=0,1,2,3,4,5$ for this option.

It may be the case that the parameters of the model may be distributed across individuals due to preference heterogeneity for the different contract attributes. To capture this preference heterogeneity, let the individual specific parameter distributions be captured by $\beta_{j, k}=\beta_{k}+\theta_{k}{ }^{\prime} Z_{j}+\sigma_{k} u_{j, k}$ for $k=0,1,2,3,4,5$, where $u_{j, k}$ is assumed to be mean zero and distributed following a one-sided triangle distribution (with $\sigma_{k}=\beta_{k}$ ) for the expected change in net returns $(\Delta R)$ parameter and normal distribution for all other attribute parameters for $k$ $=0,2,3,4,5$. The one-sided triangular distribution restricts the coefficient on expected net returns to be positive and has been found to be useful in practical applications [50]. The parameter $\sigma_{k}$ represents the standard deviation for the $k^{\text {th }}$ attribute parameter distribution; $\beta_{k}+\theta_{k}{ }^{\prime} Z_{j}$ is the conditional mean of for the $k^{\text {th }}$ attribute parameter distribution; and $Z_{j}$ is a vector of famer specific characteristics [20]. All attribute parameters were assumed to be independent of each other. 
Each parameter distribution for the model given by equation (2) is assumed to vary across the population and is conditional on a set of farmer specific characteristics. These characteristics are given by the set of explanatory variables identified in Table 2. This set of farmer specific variables provides a mechanism to incorporate geographical, socio-economic and farm characteristic variables that may impact farmers' willingness to produce a cellulosic feedstock as identified in previous studies [34-35,37-38,51-52].

While each respondent ranked their choices, we only examine the first choice or one with highest likelihood of being chosen. Thus, equation (2) is modeled using a random parameter conditional logistic regression (or mixed logit) model following Greene [20] and Train [53]. NLOGIT 4.0 [20] is used to estimate the model, using simulated maximum likelihood with 1000 Halton draws using the BFGS Quasi-Newton algorithm. Given the large number of parameters in the model (78), full model results are not presented, but are available from the authors upon request. Instead, fit statistics for the model and willingnessto-pay measures for each of the contract attributes are estimated with associated marginal effects.

A common use of econometric model results is to estimate what a producer would be willing-to-pay (WTP) for a given contract attribute. For example, what would a producer be willing to pay to reduce their contract length by 1 year? Following Greene [20], a producers willingness to pay for a (one unit change in a) contract attribute would be equal to $\beta_{k} / \beta_{1}$ for $k=2,3,4,5$. The WTP estimates provide an estimate of farmers' preferences for different attributes. Given that the attribute parameters in equation (2) are functions of farmer specific variables, mean WTP for contract attributes across the population will be equal to $\frac{\beta_{k}+\theta_{k}{ }^{\prime} Z_{j}}{\beta_{1}+\theta_{1}{ }^{\prime} Z_{j}}$ for $k=2,3,4,5$ at the mean of the conditional attribute parameter distributions. Thus, mean WTP estimates will vary with changes in farmer specific characteristics. Changes in WTP given changes in farmer specific variables (i.e. marginal effects for WTP) may be of interest, as 
well. The marginal effect of a binary variable is estimated using a discrete difference. For continuous explanatory variables, the marginal effect can be estimated as:

$$
\frac{\partial W T P_{k}}{\partial Z_{m}}=\frac{\beta_{1}\left(\partial \beta_{k} / \partial Z_{m}\right)-\beta_{k}\left(\partial \beta_{1} / \partial Z_{m}\right)}{\beta_{1}^{2}} .
$$

All mean WTP and associate marginal effects are estimated as the average across the individual estimates using the means of the conditional attribute parameter distributions. Asymptotic standard errors for mean WTP and marginal effects are estimated using the method of Krinsky and Robb [20].

\section{Results and Discussion}

Model fit statistics, as well as mean WTP estimates and marginal effect estimates are provided in Table 3. Overall, the model provided good fit with the data with a McFadden Pseudo $\mathrm{R}^{2}$ of 0.50 . In addition, the assumption of random parameters was justified as the standard deviations of the parameters for the intercept, percent gain in net returns under contract, contract length, and presence of a biorefinery harvest option were significant at the 5\% level. The choice data indicates that farmers would have adopted a contract to produce sweet sorghum 41 percent of the time across the 1385 choice situations they were asked to assess. Other survey data, which assessed the dynamics between these alternative biofuel feedstocks after the stated choice experiments were completed, indicated that survey respondents were more willing to produce a dedicated annual bioenergy crop than harvest crop residues or produce a dedicated perennial bioenergy crop.

Expected returns under the contract above corn/sorghum production had a highly significant and positive effect (at a 1\% level of significance) on a farmer's willingness to produce sweet sorghum under contract (results not shown). That is, the level of returns under the contract relative to the next best crop alternative (corn or sorghum) significantly increases the probability a farmer would grow sweet sorghum. Thus, returns will likely need to be 
higher than other competing land uses. This is strongly supported by findings in previous studies that found that net returns (and income), as well as the opportunity cost of foregone income from production enterprises not undertaken on the land, significantly impact the likelihood of a farmer growing a bioenergy crop [35-36]. Pualrud and Laitila [37] find that under contract, a farmer is willing to accept less returns for growing a dedicated bioenergy crop than if no contract is provided, potentially due to lower risk and uncertainty. In addition, the level of returns required under a contract decreased as farmer experience increased. These results are presented here as they are not readily apparent in the WTP estimates presented next.

The WTP estimates provide information about the preferences for the other contract attributes. For contract length, on average, a farmer would be willing to reduce the level of expected net returns earned per acre under the contract by $\$ 3.22$ for each year they can reduce the length of the contract. That is, a farmer would require higher net returns the longer the contract [35]. This estimate increases in absolute value by $\$ 0.13$ for each year of farm experience. As expected, farmers prefer a shorter contract, providing more flexibility for their farming operation. A potential benefit of a dedicated annual bioenergy crop is the ability to be more flexible in the short-run. Longer contracts reduce this flexibility and farmers' willingness to enter into a contract [40] Farmers are willing to reduce the amount of expected net returns by $\$ 7.50$ per acre if the biorefinery or intermediate processor provides a custom harvest option. Having a biorefinery harvest option increases the likelihood of producing sweet sorghum, providing more flexibility for timing of farming operations (e.g. interfering with the harvesting of other crops).

Insurance is an important component, especially since markets for cellulosic biomass are very limited in scope or do not exist yet in some locations. If insurance is available in the market or under the contract, then farmers would be willing to accept a contract with $\$ 6.58$ 
less in expected net returns per acre for having the risk protection provided by insurance. Thus, the availability of insurance can help to promote the adoption of sorghum biomass crops, as it has for other commodity crops [45], making it more comparable to other competing land uses. The WTP estimate for insurance was the most responsive to the socioeconomic and farm characteristics of the farmer respondents. As the percent of land rented increases by 1 percent, farmers would require $\$ 0.12$ more in expected net returns per acre under the contract when insurance is available. The cost of the land rental would likely require the farmer to seek higher returns from the land. For each additional year of experience the farmer has, they would be willing to give up an extra $\$ 0.28$ per acre in expected net returns to have insurance. In addition, for each percent increase in household income off the farm, a farmer would be willing to give up an additional $\$ 0.13$ per acre in expected net returns if insurance was available. It could be the case that additional household income from off the farm provides the farmer with more income security and flexibility, while additional experience provides them with knowledge about dealing with potential difficulties of undertaking a new enterprise [50]. As pointed out by Hipple and Duffy [34] and Sherrington et al. [36], reducing market and production uncertainty about production of dedicated bioenergy crops, should help to increase farmers' willingness to grow these crops, which can be partially alleviated with proper insurance products.

Government incentive programs have provided a strong mechanism for promoting the adoption of new enterprises and practices by farmers in the past. Such incentives could be used to promote adoption of bioenergy crops [41]. As expected, for each 1 percent increase in the level of incentive payment per ton of biomass delivered to the refiner, a farmer is willing to give up $\$ 0.30$ in expected net returns per acre. This result is obtained by assuming the response to the level of incentive is linear in the expected discounted utility function, making the WTP constant for each 1 percent increase in the incentive payment level. As with the 
other attributes, for each additional year of experience a farmer gains, the WTP increases by $\$ 0.01$ per acre. Thus, incentive payments may provide a mechanism for promoting adoption if the government wants to continue to pursue a policy to increase cellulosic biofuel production.

\section{Conclusions}

Bioenergy crops play an important role in crop production on the Great Plains and in Kansas as farmers attempt to help meet the demands for biofuel production from both grain and cellulosic feedstocks. Sweet sorghum (and other sorghum varieties) is an annual crop that is well-suited to planting in Kansas, but much uncertainty exists as to its viability and the willingness of farmers to grow such crops for biofuels. While technical feasibility studies have provided the viability of establishing an industry around these varieties of dedicated annual bioenergy crops, establishment of a functioning market will not arise if farmers are not willing to grow the crop. A stated choice survey was developed to assess farmers' willingness to grow a dedicated annual bioenergy crop for biofuels. Results from the estimation showed that farmers are more willing to grow crops if net returns are relatively high and contract length is short. In addition, results show that farmers prefer an insurance option, similar to their existing crop insurance, and that a government incentives can help to promote adoption. Furthermore, results indicate that more lucrative contracts for producers (through better pricing incentives); availability of insurance products, and shorter contracts could provide strong market incentives for farmers to enter into contracts that may not require government incentives. For example, based on the econometric model results, a $25 \%$ price incentive (per dry ton of biomass) offered by a program similar to BCAP through the U.S. federal government would lower the returns under the contract expected by the producer by $\$ 7.50$ per acre. This same effect could be obtained in a contract through reductions in 
contract length (by up to 3 years) or offering the option to harvest the bioenergy crop, providing an alternative to government subsidies.

Understanding the relative importance of key contract attributes will certainly help in designing effective incentive mechanisms to promote production of bioenergy crops. However, a contribution of this paper is in the empirical insights gained from estimated marginal effects of socio-economic and farm characteristics on the willingness-to-pay for specific contract attributes. The insights on attribute preferences based on specific socioeconomic characteristics of growers can enhance the ability of policy makers and industry players to customize the incentive mechanisms to better suit the needs and preferences of targeted grower populations. For example, risk management products (including insurance) will need to be designed for production of dedicated bioenergy crops that take into account the experience level and land tenure arrangements of the producer. Modeling results indicated that farmers with more experience and less rented land were willing to forego higher returns if insurance products were available. Sherrick et al. [54] found that more experienced farmers may be able to deal with potential losses and the interaction between insurance product choice and market conditions. Farmers with more rented land may be less likely to purchase insurance products if they benefit the land-owner more than the farm operator. Thus, the findings presented in this paper extend the literature on biofuel contracting and provide a platform for further research on drivers and impediments of farmers' adoption of dedicated annual bioenergy crops under contract.

Contract design will be one of the most important, yet most significant aspects of establishing markets and associated prices for biomass. Further research includes determining biomass prices that farmers and biorefineries can agree upon under differing contracts. As evidenced by Altman et al. [39] and Golecha and Gan [41] price will be a very important aspect of any contractual relationship. In addition, farmers face much risk and uncertainty 
with growing new crops, especially without well established markets. Designing insurance products for biomass producers that are similar to existing crop insurance is necessary before widespread bioenergy crop adoption will occur on a large scale. USDA's Risk Management Agency (RMA) must work with farmers and biorefineries to arrive at marketable insurance products. 


\section{Acknowledgements}

The funding for the primary portion of this project came from the South Central Sun Grant Initiative and Department of Transportation (Award No. DTOS59-07-G-00053). This provided funds for salary support, graduate student funding, and survey data collection. Additional funds from the National Science Foundation, EPSCoR Division, Research Infrastructure Improvement (Award No. 0903806) were utilized for salary support and graduate student support in this research. The National Science Foundation Grant From Crops to Commuting: Integrating the Social, Technological, and Agricultural Aspects of Renewable and Sustainable Biorefining (I-STAR; Award No. DGE-0903701) provided additional graduate student support. 


\section{References}

[1] U.S. Congress, House of Representatives. "Energy Independence and Security Act of 2007. Title II-Energy Security Through Increased Production of Biofuels; Subtitle ARenewable Fuel Standard." U.S. Government Printing Office, 2007.

[2] Energy Information Administration (EIA). "Cellulosic Biofuels Begin to Flow but in Lower Volumes than Foreseen by Statutory Targets.” Today in Energy. February 26, 2013. [3] Environmental Protection Agency (EPA). EPA Finalizes Regulations for the National Renewable Fuel Standard Program for 2010 and Beyond. Regulatory Announcement. EPA420-F-10-007. February 2010.

[4] Environmental Protection Agency (EPA). “EPA Finalizes 2013 Renewable Fuel Standards.” Regulatory Announcement. EPA-420-F-13-042. , U.S. Office of Transportation and Air Quality, August 2013.

[5] D. Rajagopal and D. Zilberman. "Review of Environmental, Economic and Policy Aspects of Biofuels.” Vol. 4341. World Bank Publications 2007.

[6] M. Calvino and J. Messing. "Sweet Sorghum as a Model System for Bioenergy Crops." Current Opinion in Biotechnology Vol. 23, pp. 323-329, 2012.

[7] J.L. Propheter, S. A. Staggenborg, X. B. Wu, and D. Wang. "Performance of Annual and Perennial Biofuel Crops: Yields during the First Two Years." Agronomy Journal, Vol. 102, pp. 806-814, 2010.

[8]D. Rajagopal, S.E. Sexton, D. Roland-Holst and D. Zilberman. "Challenge of Biofuel: Filling the Tank without Emptying the Stomach?” Environmental Research Letters. Vol. 2 (4), 2007.

[9] Williamson, O. E. "Markets and Hierarchies: Some Elementary Considerations". in: Strategy: Critical Perspectives on Business and Management Volume IV, D. Faulkner, ed. New York, NY: Routledge, pp. 106 - 118, 2002. 
[10] Joskow, P. L. "Contract Duration and Relationship-Specific Investments: Empirical Evidence from Coal Markets". The American Economic Review, Vol. 77(1), pp. 168 - 185, 1987.

[11] Osborn, R. N., and Baughn, C. C. "Forms of Interorganizational Governance for Multinational Alliances". Academy of Management Journal, Vol. 33(3), pp. 503-519,1990.

[12] Peterson, H. C., Wysocki, A., \& Harsh, S. B. "Strategic Choice Along the Vertical Coordination Continuum". The International Food and Agribusiness Management Review, Vol. 4(2), pp. 149-166, 2001.

[13] Altman, I., C.R. Boessen and D.R. Sanders. "Contracting for Biomass: Supply Chain Strategies for Renewable Energy.” Paper presented at the Southern Agricultural Economics Association Annual Meeting, Mobile, Alabama, February 3 - 6, 2007. Available at: http://ageconsearch.umn.edu/ bitstream/34907/1/sp07al01.pdf.

[14] Clark, R.K. Roberts and S. Hwang. "Challenges to the Development of a Dedicated Energy Crop.” American Journal of Agricultural Economics. Vol. 89, pp. 1296 - 1302, 2007. [15] Glassner, D.A., J.R. Hettenhaus and T.M. Schechinger. "Corn Stover Collection Project.” Paper presented at BioEnergy '98: Expanding Bioenergy Partnerships, Madison, Wisconsin, October 4 - 8, 1998. Available at:

http://ergosphere.files.wordpress.com/2007/04/bio98_corn_stover.pdf.

[16] Larson, J.A., B.C. English and L. Lambert. "Economic Analysis of the Conditions for Which Farmers Will Supply Biomass Feedstocks for Energy Production.” Final Report for Agricultural Marketing Center Special Projects Grant 412-30-54, Agricultural Marketing Resource Center, University of Tennessee, 2007. Available at: http://www.agmrc.org/media/cms/2007UTennProjDeliverable_9BDDFC4C2F4E5.pdf. [17] Stricker, J.A., S.A. Segrest, D.L. Rockwood and G.M. Prine. "Model Fuel Contract Co-Firing Biomass with Coal." Paper presented at the Soil and Crop Science Society of Florida and Florida Nematology Forum, $60^{\text {th }}$ Annual Meeting, Tallahassee, Florida, 
September 20 - 22, 2000. Available at: http://www.techtp.com/

Cofiring/Model\%20Contract\%20Cofiring\%20Biomass\%20with\%20Coal.pdf.

[18] Wilhelm, W.W. J.M.F. Johnson, J.L. Hatfield, W.B. Voorhees and D.R. Linden. “Crop and Soil Productivity Response to Corn Residue Removal: A Literature Review.” Agronomy Journal. Vol. 96, pp.1 - 17, 2004.

[19] J.J. Louviere, D.A. Hensher and J.D. Swait. Stated Choice Methods: Analysis and Application. Cambridge, UK: Cambridge University Press, 2000.

[20] W.H. Greene, Econometric Analysis, $7^{\text {th }}$ Ed. New Jersey: Pearson Prentice Hall, 20012. [21] D.A. Hensher, D.A., J.M. Rose, and W.H. Greene. Applied Choice Analysis: A Primer. Cambridge UK: Cambridge University Press, 2005.

[22] Babcock, B. A., P. W. Gassman, M. Jha, and C. L. Kling. "Adoption Subsidies and Environmental Impacts of Alternative Energy Crops.” Briefing Paper 07-BP 50, Center for Agricultural and Rural Development, Iowa State University, Agricultural Marketing Resource Center, 2007. Available at: http://www.iatp.org/files/258_2_97936.pdf. [23] Epplin, F.M., C.D. Clark, R.K. Roberts, and S. Hwang. "Challenges to the Development of a Dedicated Energy Crop." American Journal of Agricultural Economics Vol. 89(5), pp. 1296-1302, 2007.

[24] Gallagher, P.W., M. Dikeman, J. Fritz, E. Wailes, W. Gauthier and H. Shapouri. "Supply and Social Cost Estimates for Biomass from Crop Residues in the United States." Environmental and Resource Economics Vol. 24, pp. 335-358, 2003.

[25] Graham, R.L., R. Nelson, J. Sheehan, R. D. Perlack, and L.L. Wright. "Current and Potential U.S. Corn Stover Supplies." Agronomy Journal Vol. 99, pp. 1-11, 2007. [26] Graham, R.L. "An Analysis of the Potential Land Base for Energy Crops in the Conterminous United States." Biomass and Bioenergy, Vol. 6(3), pp. 175-189, 1994. 
[27] McLaughlin, S.B., D.G. De La Torre Ugarte, C.T. Garten, Jr. L.R. Lynd, M. Sanderson, V.R. Tolbert, and D.D. Wolf. "High-Value Renewable Energy from Prairie Grasses."

Environmental Science and Technology, Vol. 36(10), pp. 2122-2129, 2002.

[28] Nelson, R.G. "Resource Assessment and Removal Analysis for Corn Stover and Wheat Straw in the Eastern and Midwestern United States - Rainfall and Wind-Induced Soil Erosion Methodology." Biomass and Bioenergy Vol. 22(5), pp. 349-363, 2002.

[29] Paine, L.K., T.L. Peterson, D.J. Undersander, K.C. Rineer, G.A. Bertelt, S.A. Temple, D.W. Sample, and R.M. Klemme. "Some Ecological and Socio-Economic Considerations for Biomass Energy Crop Production." Biomass and Bioenergy Vol. 10(4), pp. 231-242, 1996. [30] Perlack, R.D., L.L. Wright, A.F. Turhollow, R.L. Graham, B.J. Stokes, and D.C. Erbach. "Biomass as Feedstock for a Bioenergy and Bioproducts Industry: The Technical Feasibility of a Billion-Ton Annual Supply.” Technical Report, Oak Ridge National Laboratories, 2005. Available at:

http://oai.dtic.mil/oai/oai?verb=getRecord\&metadataPrefix=html\&identifier=ADA436753.

[31] Propheter, J.L., S.A. Staggenborg, X.B. Wu, and D. Wang. "Performance of Annual and Perennial Biofuel Crops: Yields during the First Two Years." Agronomy Journal Vol. 102(2), pp. 806-814, 2010.

[32] Turhollow, A. "The Economics of Energy Crop Production." Biomass and Bioenergy, Vol. 6(3), pp. 229-241, 1994.

[33] Walsh, M.E., D.G. De La Torre Ugarte, H.Shapouri, and S.P. Slinsky. "Bioenergy Crop Production in the United States." Environmental and Resource Economics Vol. 24, pp. 313333, 2003.

[34] P.C. Hipple and M. D. Duffy. "Farmers' Motivations for Adoption of Switchgrass." In: Trends in New Crops and New Uses, edited by J Janich and A Whipkey, Alexandria, VA: AS HA Press, pp. 252-266, 2002. 
[35] K. Jensen, C. D. Clark, P. Ellis, B. English, J. Menard, M. Walsh and D. de la Torre Ugarte "Farmer Willingness to Grow Switchgrass for Energy Production." Biomass and Bioenergy, Vol. 31, pp. 773 - 781, 2007.

[36] Sherrington, C., J. Bartley and D. Moran. "Farm-level Constraints on the Domestic Supply of Perennial Energy Crops in the UK.” Energy Policy, Vol. 36, pp. $2504-2512$, 2008.

[37] S. Paulrud and T. Laitila. "Farmers' Attitudes about Growing Energy Crops: A Choice Experiment Approach." Biomass and Bioenergy, Vol, 34, pp. 1770-1779, 2010.

[38] D. J. Qualls, K. L. Jensen, C. D. Clark, B. C. English, J. A. Larson, and S. T. Yen. "Analysis of Factors Affecting Willingness to Produce Switchgrass in the Southeastern United States.” Biomass and Bioenergy, Vol. 39, pp. 159-167, 2012.

[39] Altman, I., J. Bergtold, D. Sanders and T. Johnson. "Willingness to Supply Biomass for Bioenergy Production: A Random Parameter Truncated Analysis.” Energy Economics, Vol. 47, pp. $1-10,2015$.

[40] Alexander, C., R. Ivanic, S. Rosch, W. Tyner, S.Y. Wu and J.R. Yoder. “Contract Theory and Implications for Perennial Energy Crop Contracting.” Energy Economics, Vol. 34, pp. $970-979,2012$.

[41] Golecha, R. and J. Gan. “Optimal Contracting Structure Between Cellulosic Biorefineries and Farmers to Reduce the Impact of Biomass Supply Variation: Game Theoretic Analysis.” Biofuels, Bioproducts and Biorefining, Vol. 10, pp. 129 - 138, 2016. [42] National Agricultural Statistics Service, U.S. Department of Agriculture (USDA-NASS). "2012 Census Volume 1, Chapter 1: State Level." 2013. Available at: http://www.agcensus .usda.gov/Publications/2012/Full_Report/Volume_1,_Chapter_1_State_Level/. 
[43] B. Roe, T.L. .Sporleder and B. Belleville. "Hog Producer Preferences for Marketing Contract Attributes," American Journal of Agricultural Economics, Vol 86, pp. 115 - 123, 2004.

[44] Kansas Farm Management Association"Summary Reports by Region.”, 2010 Available at: http://www.agmanager.info/kfma/

[45] Wu, J.J. “Crop Insurance, Acreage Decisions, and Nonpoint Source Pollution.” American Journal of Agricultural Economics, Vol. 81, pp. 305 - 320, 1999.

[46] M. Khanna, X. Chen, H. Huang and H. Onal, "Land Use and Greenhouse Gas Mitigation Effects of Biofuel Policies" University of Illinois Law Review, Vol. 2011, pp. 549-588, 2011. [47] SAS Institute, Inc. SAS for Windows, Version 9.2. Cary, NC., 2008.

[48] N.K. Nguyen and A. Miller. "A Review of Exchange Algorithms for Constructing Discrete D-optimal Designs," Computational Statistics \& Data Analysis, Vol. 14, pp. 489498, 1992.

[49] R.D. Cook and C.J. Nachtsheim, "Computer-Aided Blocking of Factorial and ResponseSurface Designs," Technometrics, Vol. 31, pp. 339-346, 1989.

[50] W.H. Greene, NLOGIT, Version 5 Reference Guide, Econometric Software, Inc. Plainview, NY. 2012.

[51] J.E. Fewell, M.K. Lynes, J.R. Williams and J.S. Bergtold. “Kansas Farmers' Interest and Preferences for Growing Cellulosic Bioenergy Crops.” Journal of American Association of Farm Managers and Rural Appraisers, pp. 132 - 153, 2013. Available at: http://ageconsearch.umn.edu/bitstream/161493/2/385\%20Williams.pdf. [52] D.J. Pannell, G. R. Marshall, N. Barr, A. Curtis, F. Vanclay and R. Wilkinson. "Understanding and Promoting Adoption of Conservation Practices by Rural Landholders." Australian Journal of Experimental Agriculture, Vol. 46, pp. 1407-1424, 2006. 
[53] K.E. Train, Discrete Choice Methods with Simulation. Cambridge, UK: Cambridge University Press, 2003.

[54] Sherrick, B.J., P.J. Barry, P.N. Ellinger and G.D. Schnitkey. "Factors Influencing Farmers' Crop Insurance Decisions." American Journal of Agricultural Economics, Vol. 86, pp. $103-114,2004$. 
Table 1: Descriptive Statistics for Explanatory Variables $(N=277)$

\begin{tabular}{|c|c|c|c|}
\hline Variable Name & Definition & Mean & $\begin{array}{l}\text { Standard } \\
\text { Deviation }\end{array}$ \\
\hline East & $\begin{array}{l}\text { Equal to } 1 \text { if farmer is located in eastern } \\
\text { Kansas and } 0 \text { otherwise. }\end{array}$ & 0.37 & 0.49 \\
\hline West & $\begin{array}{l}\text { Equal to } 1 \text { if farmer is located in western } \\
\text { Kansas and } 0 \text { otherwise. }\end{array}$ & 0.34 & 0.48 \\
\hline Farm Size & Size of farm in acres & 2150 & 1665 \\
\hline Percent Rent & Percent of farm land rented. & 57.7 & 34.7 \\
\hline Crop Sales Percent & $\begin{array}{l}\text { Percent of gross farm sales from crop } \\
\text { production. }\end{array}$ & 70.8 & 26.5 \\
\hline Off-Farm Income & $\begin{array}{l}\text { Percent of household income earned off the } \\
\text { farm. }\end{array}$ & 34.4 & 36.7 \\
\hline Experience & Number of years farming & 32.0 & 13.1 \\
\hline Crop Rotation & $\begin{array}{l}\text { Equal to } 1 \text { if farmer uses a crop rotation } \\
\text { and } 0 \text { otherwise. }\end{array}$ & 0.38 & 0.49 \\
\hline Risk Averse & $\begin{array}{l}\text { Equal to } 1 \text { if the farmer considers } \\
\text { themselves averse to risk and } 0 \text { otherwise. }\end{array}$ & 0.89 & 0.32 \\
\hline College & $\begin{array}{l}\text { Equal to } 1 \text { if the farmer has a college } \\
\text { degree and } 0 \text { otherwise. }\end{array}$ & 0.30 & 0.46 \\
\hline Grow Sorghum & $\begin{array}{l}\text { Equal to } 1 \text { if the farmer has grown } \\
\text { sorghum before and } 0 \text { otherwise. }\end{array}$ & 0.47 & 0.50 \\
\hline
\end{tabular}


Table 2: Contract Attributes and Levels for Stated Choice Experiments for Sweet Sorghum

\begin{tabular}{|c|c|c|}
\hline $\begin{array}{l}\text { Contract } \\
\text { Attribute }\end{array}$ & Description & Levels \\
\hline $\begin{array}{l}\text { Net Returns (for } \\
\text { all features of the } \\
\text { contract except } \\
\text { cost-share and } \\
\text { government } \\
\text { payments) }\end{array}$ & $\begin{array}{l}\text { Represents the expected percentage gain under the } \\
\text { contract above net returns associated with } \\
\text { corn/sorghum production on a farmer's operation. } \\
\text { As a reference point, on average, returns from } \\
\text { corn/sorghum production are expected to be } \$ 50 \text { per } \\
\text { acre in Kansas. }\end{array}$ & $\begin{array}{l}0 \%, 15 \%, 30 \% \\
\text { and } 45 \%\end{array}$ \\
\hline Contract Length & $\begin{array}{l}\text { Represents the time commitment in consecutive } \\
\text { years of the contractual agreement. }\end{array}$ & 2,5 and 8 years \\
\hline $\begin{array}{l}\text { Biorefinery } \\
\text { Harvest }\end{array}$ & $\begin{array}{l}\text { "Yes" indicates the bio-refinery will harvest the } \\
\text { biomass at their expense, and "No" means the } \\
\text { farmer is responsible for harvest (including cutting, } \\
\text { raking, baling and transportation to the bio-refinery). } \\
\text { Harvest charges are included in the percentage net } \\
\text { return. That is, the charges are considered paid } \\
\text { regardless of who harvests the biomass. }\end{array}$ & Yes or No \\
\hline $\begin{array}{l}\text { Insurance } \\
\text { Availability }\end{array}$ & $\begin{array}{l}\text { "Yes" indicates crop insurance is available, and } \\
\text { "No" otherwise. }\end{array}$ & Yes or No \\
\hline $\begin{array}{l}\text { Government } \\
\text { Incentive } \\
\text { Payment }\end{array}$ & $\begin{array}{l}\text { This incentive payment is provided at two levels for } \\
\text { production of cellulosic biofuel feedstocks delivered } \\
\text { to a bio-refinery. The incentive levels are either } \\
\text { none }(0) \text { or } 25 \text { percent of the price per dry ton of } \\
\text { biomass delivered to the refinery. The incentive } \\
\text { received is in addition to the net returns above } \\
\text { production. }\end{array}$ & $0 \%$ and $25 \%$ \\
\hline
\end{tabular}


Table 3: Willingness-to-Pay (\$/acre), Associated Marginal Effect (\$/acre) Estimation Results, and Model Fit Statistics

\begin{tabular}{|c|c|c|c|c|}
\hline & $\begin{array}{l}\text { Contract } \\
\text { Length }\end{array}$ & $\begin{array}{l}\text { Biorefinery } \\
\text { Harvest }\end{array}$ & $\begin{array}{c}\text { Insurance } \\
\text { Availability }\end{array}$ & $\begin{array}{c}\text { Government } \\
\text { Incentive Payment }\end{array}$ \\
\hline Mean & \multicolumn{3}{|c|}{$\begin{array}{c}\text { Mean Willingness-to-Pay Across Respondents }{ }^{\mathrm{a}} \\
\text { (Standard Error) }\end{array}$} & $\begin{array}{l}\text { dents }^{\mathrm{a}} \\
\\
\quad \$ 0.30^{* *} \\
(\$ 0.11)\end{array}$ \\
\hline & \multicolumn{4}{|c|}{$\begin{array}{l}\text { Marginal Effect on Willingness-to-Pay }{ }^{\mathrm{a}} \\
\text { (Standard Error) }\end{array}$} \\
\hline East & $\begin{array}{l}-\$ 1.32 \\
(\$ 2.72)\end{array}$ & $\begin{array}{l}\$ 1.03 \\
(\$ 5.14)\end{array}$ & $\begin{array}{c}\$ 1.91 \\
(\$ 7.24)\end{array}$ & $\begin{array}{c}\$ 0.12 \\
(\$ 0.24)\end{array}$ \\
\hline West & $\begin{array}{l}-\$ 2.59 \\
(\$ 3.09)\end{array}$ & $\begin{array}{l}-\$ 4.33 \\
(\$ 5.96)\end{array}$ & $\begin{array}{l}\$ 4.64 \\
(\$ 8.21)\end{array}$ & $\begin{array}{l}\$ 0.03 \\
(\$ 0.26)\end{array}$ \\
\hline Farm Size & $\begin{array}{l}-\$ 2.34 \mathrm{E}-4 \\
(\$ 3.50 \mathrm{E}-4)\end{array}$ & $\begin{array}{l}\$ 7.26 \mathrm{E}-4 \\
(\$ 7.99 \mathrm{E}-4)\end{array}$ & $\begin{array}{c}\$ 0.001 \\
(\$ 9.70 \mathrm{E}-4)\end{array}$ & $\begin{array}{l}\$ 3.48 \mathrm{E}-5 \\
(\$ 3.51 \mathrm{E}-5)\end{array}$ \\
\hline Percent Rent & $\begin{array}{c}\$ 0.02 \\
(\$ 0.02)\end{array}$ & $\begin{array}{l}\$ 2.38 \mathrm{E}-4 \\
(\$ 0.04)\end{array}$ & $\begin{array}{l}-\$ 0.12^{*} \\
(\$ 0.05)\end{array}$ & $\begin{array}{l}-\$ 5.78 \mathrm{E}-4 \\
(\$ 0.002)\end{array}$ \\
\hline Crop Sales & $-\$ 0.02$ & $\$ 0.07$ & $\$ 0.07$ & $\$ 5.73 E-4$ \\
\hline Percent & $(\$ 0.02)$ & $(\$ 0.05)$ & $(\$ 0.06)$ & $(\$ 0.002)$ \\
\hline Off-Farm & $-\$ 0.01$ & $\$ 0.02$ & $\$ 0.13^{*}$ & $-\$ 2.93 \mathrm{E}-4$ \\
\hline Income & $(\$ 0.02)$ & $(\$ 0.04)$ & $(\$ 0.06)$ & $(\$ 0.002)$ \\
\hline Experience & $\begin{array}{l}-\$ 0.13^{*} \\
(\$ 0.04)\end{array}$ & $\begin{array}{l}\$ 0.13 \\
(\$ 0.13)\end{array}$ & $\begin{array}{l}\$ 0.28^{*} \\
(\$ 0.13)\end{array}$ & $\begin{array}{c}\$ 0.01 * \\
(\$ 0.005)\end{array}$ \\
\hline Crop Rotation & $\begin{array}{l}-\$ 0.08 \\
(\$ 2.81)\end{array}$ & $\begin{array}{l}-\$ 1.43 \\
(\$ 5.26)\end{array}$ & $\begin{array}{l}-\$ 2.91 \\
(\$ 7.80)\end{array}$ & $\begin{array}{c}\$ 0.07 \\
(\$ 0.23)\end{array}$ \\
\hline Risk Averse & $\begin{array}{l}-\$ 0.11 \\
(\$ 2.45)\end{array}$ & $\begin{array}{l}\$ 7.85 \\
(\$ 5.06)\end{array}$ & $\begin{array}{c}\$ 3.46 \\
(\$ 6.56)\end{array}$ & $\begin{array}{l}-\$ 0.03 \\
(\$ 0.23)\end{array}$ \\
\hline College & $\begin{array}{l}\$ 0.65 \\
(\$ 2.36)\end{array}$ & $\begin{array}{l}-\$ 1.18 \\
(\$ 4.61)\end{array}$ & $\begin{array}{c}\$ 0.98 \\
(\$ 6.89)\end{array}$ & $\begin{array}{l}-\$ 0.10 \\
(\$ 0.19)\end{array}$ \\
\hline Grow Sorghum & $\begin{array}{c}\$ 1.41 \\
(\$ 2.48)\end{array}$ & $\begin{array}{l}-\$ 2.02 \\
(\$ 4.93)\end{array}$ & $\begin{array}{c}\$ 2.37 \\
(\$ 7.23)\end{array}$ & $\begin{array}{l}-\$ 0.11 \\
(\$ 0.21)\end{array}$ \\
\hline
\end{tabular}

Log Likelihood

Model Fit Statistics

McFadden Pseudo $\mathrm{R}^{2}$

$-765.7728$

Number of Observations

** and $*$ denote statistical significance at the 5 and 10 percent levels, respectively.

${ }^{a}$ All estimates of willingness-to-pay and associated marginal effects were estimated using the estimated mean of the conditional parameter distribution for each random parameter in the logistic regression model estimated. Asymptotic standard errors were estimated using the method of Krinsky and Robb [20]. Both mean and standard error estimates were estimated cutting off the tails at the 5\% level of the empirical distributions of WTP to avoid extreme estimates [20]. 


\begin{tabular}{|c|c|c|c|c|}
\hline \multicolumn{2}{|c|}{ Sweet Sorghum Scenario: } & Contract A & Contract B & Option C \\
\hline \multirow{5}{*}{ 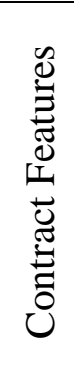 } & $\begin{array}{c}\text { Net Return Above } \\
\text { Sorghum/Corn Production } \\
\text { (Base: } \$ 50 / \text { ac) }\end{array}$ & 45\% Higher/year & $0 \%$ Higher/year & \multirow{5}{*}{$\begin{array}{c}\text { Do Not } \\
\text { Adopt }\end{array}$} \\
\hline & Contract Length & 5 Years & 2 Years & \\
\hline & Biorefinery Harvest & Yes & No & \\
\hline & Insurance Availability & No & No & \\
\hline & Gov. Incentive Payment & None & $25 \%$ & \\
\hline & $\begin{array}{c}\text { Your Ranking } \\
\quad(1-3)\end{array}$ & 2048 & 2049 & 2050 \\
\hline
\end{tabular}

Figure 1: Example Choice Scenarios/Questions for Stated Choice Experiment 